Research article

\title{
Recovery of Food Wastes for a Potential Maggot Production as Animal Feed and Solid Waste Management
}

\author{
Timoth Mkilima ${ }^{1,2 *}$
}

1 Department of Civil Engineering, L.N. Gumilyov Eurasian National University, Satpayev street 2, 010000, Nur-Sultan, Kazakhstan; tmkilima@gmail.com (T.M)

2 Department of Environmental Engineering, Ardhi University, Observation Hill, Plot No. 3, Block L, University Road, Dar es Salaam, Tanzania

* Correspondence: tmkilima@gmail.com

\begin{abstract}
Waste recovery is an important aspect of human and environmental health protection. Unfortunately, proper food waste management is among the serious challenges in the field of solid waste management worldwide. Therefore, it is of great importance to conduct studies towards achieving efficient and cost-effective approaches for food waste management. This study investigated the potential of recovering food waste through maggots' production as animal feed. The influence of fly attractant application on maggot production was also investigated. The study also investigated the potential of maggot production for waste recovery and reduction. Four different types of food waste (starch food leftovers, rotten bananas and peels, rotten pineapple and peels, and rotten oranges) were used in the investigation process. From the results, it was observed that the application of fly attractants had a significant effect on the production of maggots as determined by the weights after harvesting. An average weight of $94 \mathrm{~g} / \mathrm{kg}$ of maggot was achieved from banana materials with an application of fly attractant during the 8th day of the cultivation; which is equivalent to a $32.4 \%$ increase from the same day when the material was cultured without applying fly attractant. Also, from the starch materials, about $77 \mathrm{~g} / \mathrm{kg}$ of maggot weight was achieved; which is a $54.6 \%$ increase from the same day and the same material but without application of fly attractant. Moreover, the relative dry weight reduction in the trials varied from $52.5 \%$ to $82.4 \%$.
\end{abstract}

Keywords: food waste recovery; maggot production; environmental protection; animal feed; solid waste management

\section{Introduction}

Due to the high population growth around the world, the demand for food has also been increasing tremendously. However, the growth in food demand goes parallel with the high production of food waste [1-3]. In that matter, millions of tons of food waste are generated every day globally. According to the literature, an estimated 1.3 billion tons of food is wasted worldwide every year, this is approximately one-third of all food produced for human consumption, as reported by the Food and Agriculture Organization (FAO) of the United Nations [4].

Unfortunately, the capacity of handling such a huge waste is also highly constrained by financial capacities $[5,6]$. This becomes are a serious issue of concern in low-income communities. There are many approaches currently in use for the management of food waste such as landfilling [7], composting [8], food waste disposer [9,10], and direct anaerobic digestion [11]. However, each approach is linked to a number of drawbacks.

For instance, landfills have been widely used for the disposal of food waste [12-14]. However, the challenge is that food waste that ends up in landfills rots and produces a large amount of methane which is a highly powerful greenhouse gas [15]. It has to be noted that, the excess amounts of greenhouse gases such as methane, carbon dioxide, and 
chlorofluorocarbons are associated with the absorption of infrared radiation and heat the earth's atmosphere, causing global warming and climate change in general [16-18].

Therefore, it is highly important to investigate and develop readily available, economical, and environment-friendly approaches for the recovery of food waste for the protection of human health and the environment in general. Maggots' production as animal feed stands to be among the relatively cost-effective approaches for food waste recovery $[19,20]$. Maggots can be defined as fly larvae, typically of the common housefly as well as the bluebottle [21]. The production mechanism is that flies are attracted to food and other sorts of rubbish and then they lay their eggs on the rubbish and eventually the eggs hatch into the so-called maggots [22]. Unfortunately, the information on how maggot production can be a useful tool for food waste management is still scarce.

The flies can effectively convert organic waste into a proteins-rich end product that is an excellent source for animal feed [23]. While the leftover product remaining from the decomposition process can be used as a high nitrogen organic fertilizer. For example, it is estimated that producing 1 kilogram of farmed fish in any aquaculture system can require approximately 1-8 kilograms of feed [24]. Mostly, in the field of fish farming, the fish feed is made up almost entirely of raw materials such as straw meal [25], soybean cake [26], peanut cake [27], corn protein powder, rice bran [28], and wheat bran [29], which in turn has been increasing raw material competition.

Moreover, raising chickens in poultry farms is equally challenging at the moment from the high feed demand [30]. It is estimated that chickens require double the amount of grain in comparison to the meat they produce [31]. In general, the demand for feed has made nearly $40 \%$ of all grain produced in the world end up as animal feed [32].

However, many factors can affect the productivity of maggots $[33,34]$ including the factors related to the substrate initial conditions and the type of material used for the production. Unfortunately, there are no sufficient studies yet to provide enough information on how these factors would affect the productivity of maggots on different food waste materials. Also, the information on the potential of maggot production for waste recovery and reduction based on different substrate materials is still scarce.

In this study, the potential of recovering food waste through maggots' production is investigated. The influence of different factors such as time and application of fly attractants on maggot production are also investigated. Four different types of food waste (starch food leftovers, rotten bananas and peels, pineapple peels, and rotten oranges) are used in the investigation process. The breeding vats are divided into those of 5-day harvesting, 6-day harvesting, 7-day harvesting, and 8-day harvesting. Also, the amount of waste reduced by maggots from the investigated substrate materials is computed to investigate the potential of maggot production for organic waste reduction. Furthermore, box and whisker plots are developed to evaluate the data distributions among the selected maggot production parameters.

\section{Materials and Methods}

Material collection, processing, and experimental setup

In this study, the substrate materials were grouped into four categories; starch food leftovers (rice, pieces of bread, and corn stiff porridge), rotten bananas and peels, rotten pineapples and peels as well as rotten oranges. The materials were collected from different parts of Dar es Salaam, including restaurants and markets. Dar es Salaam is a city located in Tanzania and former capital city and remains to be the largest city in Tanzania in terms of population.

The materials were grouped accordingly and ground into smaller particles using a grinding machine. Also, the materials were properly mixed before introducing into the breeding vats. The general flowchart is summarized in Figure 1. Before starting the experiments, all the substrates used in this study were placed in an air-tight container for more 
than 12 hours to eliminate the potential fly eggs or larvae that could be present in the substrate when collecting the materials.

For all the experiments, a substrate of $2 \mathrm{~kg}$ was used. For the substrates that contained fly attractants, approximately $0.25 \mathrm{~kg}$ of fly attractants composed of blood, meat debris, and rotten eggs and placed randomly in the breeding vats. The breeding vats were then exposed for around 8 hours to attract houseflies as a process of naturally laying their eggs. After exposing the breeding vats, the substrates were covered using perforated polythene cover to provide shading. To make sure that moisture is maintained in breeding vats, water had to be sprinkled at least once per day.

In general, the study had two main cases; case number one was based on the group of substrates that was cultured without adding fly attractant. While case number two is based on the group of substrates mixed with fly attractant. Both cases were investigated under 5-day harvesting, 6-day harvesting, 7-day harvesting, and 8-day harvesting. Fresh organic substrates composed of starch food leftovers (rice, pieces of bread, and corn stiff porridge), rotten bananas and peels, rotten pineapples and peels as well as rotten oranges were collected around the city.

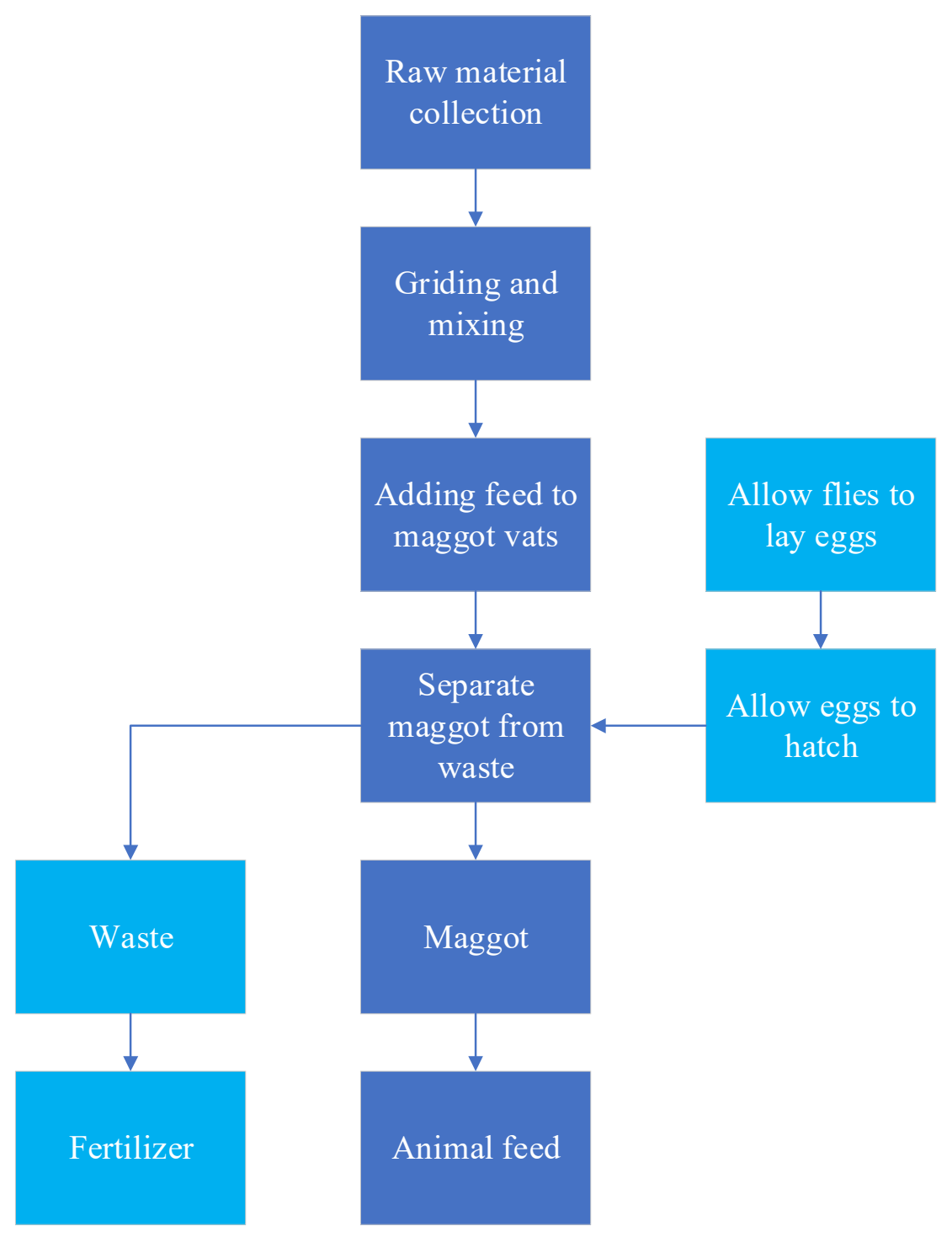

Figure 1. General flowchart of the maggot production processes 
The breeding vats were divided into those of 5-day harvesting, 6-day harvesting, 7day harvesting, and 8-day harvesting. The $\mathrm{pH}$ in the substrates was measured using Conical-tip electrodes (Mettler Toledo, Columbus, Ohio, United States).

\section{Statistical methods}

To investigate the relationship among the studied parameters, correlation matrices were developed. These matrices were important to evaluate the strength of the relationship among the potential selected parameters affecting maggot production. From the matrices, a high correlation indicated that two or more variables had a strong relationship with each other. While a weak correlation meant that the variables were hardly related. Table 1 provides a summary of the interpretation of the correlation indices used in this study.

Table 1. Interpretation of the correlation coefficients

\begin{tabular}{cc}
\hline Range of correlation coefficient & Strength of relationship \\
\hline $0-0.29$ & Weak \\
$0.3-0.49$ & Moderate \\
$0.5-0.69$ & Strong \\
$0.7-1$ & Very strong \\
\hline
\end{tabular}

Moreover, box and whisker plots were created to evaluate the data distributions among the selected maggot production parameters. The evaluation is based on the distribution of numerical data and skewness through data quartiles (percentiles) and averages. In general, box plots show the five-number summary of a set of data: the minimum score, first (lower) quartile, median, third (upper) quartile, and maximum score.

\section{Results and discussion}

The investigation of maggot production from food wastes based on the main two cases (substrates without fly attractant and substrates with an application of fly attractant) was successfully executed. The weight of the maggots was expressed in terms of $\mathrm{g}$ per $\mathrm{kg}$ of dry substrate. The $\mathrm{pH}$ levels in the substrates were observed to be fluctuating with no specific trend with time. The phenomenon led to low correlation indices between $\mathrm{pH}$ and other parameters.

Time was also another important factor investigated for maggot production and waste reduction. In this study, the maggot production is based on four different groups of days starting from day 5 . In the literature, it has been observed that maggots can shed or cast off their outer layer twice during the development process and can grow up to 20 $\mathrm{mm}$ in length in four days. In that matter, upon being supplied with the necessary food nutrients that are also determined by the substrate material, they, in turn, retire into their puparia where the transformation occurs [22].

From banana (day 5), $48 \mathrm{~g} / \mathrm{kg}$ was recorded as the minimum maggot weight, with 56 $\mathrm{g} / \mathrm{kg}$ being the maximum recorded weight. While $51.5 \mathrm{~g} / \mathrm{kg}$ was the average weight from the banana materials and day 5 when the substrates were cultured without an application of fly attractant. From orange materials (day 5) without application of fly attractant; a minimum value of $46 \mathrm{~g} / \mathrm{kg}$ maggot weight was recorded; a maximum value of $53 \mathrm{~g} / \mathrm{kg}$ was recorded and an average weight of $50 \mathrm{~g} / \mathrm{kg}$ was achieved from the data series.

From the pineapple materials (day 5); $46 \mathrm{~g} / \mathrm{kg}$ was recorded as the minimum weight value and $55 \mathrm{~g} / \mathrm{kg}$ was recorded as the maximum weight value, while $\quad 49.75 \mathrm{~g} / \mathrm{kg}$ was the average maggot weight without an application of fly attractant.

Also, from the starch materials without fly attractant; a minimum recorded wight value of $28 \mathrm{~g} / \mathrm{kg}$ was recorded with $42 \mathrm{~g} / \mathrm{kg}$ being the maximum recorded weight value. While $36 \mathrm{~g} / \mathrm{kg}$ was the average weight. 


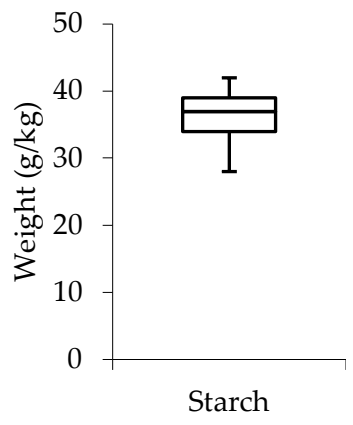

(a)

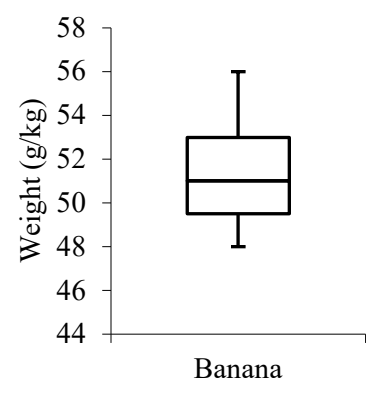

(b)

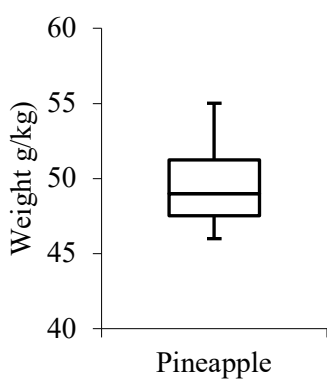

(c)

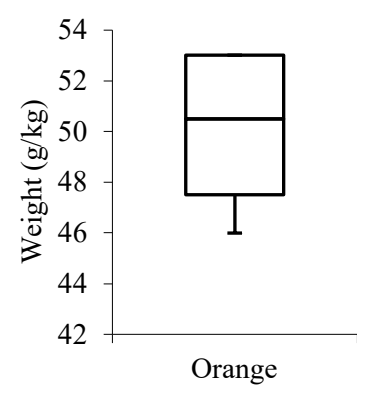

(d)

Figure 2. Day 5 harvesting with the substrate without fly attractant from different waste materials (a) starch (b) bananas (c) pineapples (d) oranges

Also, some of the substrates were harvested on day 6; From data series, it was observed that the combination of banana material, day 6 and without application of fly attractant, $48 \mathrm{~g} / \mathrm{kg}$ was achieved as the minimum recorded maggot weight, with $60 \mathrm{~g} / \mathrm{kg}$ being the maximum recorded weight. While $54 \mathrm{~g} / \mathrm{kg}$ was the average weight. From orange materials under day 6 and without application of fly attractant; a minimum value of $49 \mathrm{~g} / \mathrm{kg}$ maggot weight was recorded; a maximum value of $58 \mathrm{~g} / \mathrm{kg}$ was recorded and an average weight of $53 \mathrm{~g} / \mathrm{kg}$ was recorded from the list of datasets.

When the maggots were harvested from pineapple materials under day 6; 51

$\mathrm{g} / \mathrm{kg}$ was recorded as the minimum weight value and $59 \mathrm{~g} / \mathrm{kg}$ was recorded as the maximum weight value, while $54.5 \mathrm{~g} / \mathrm{kg}$ was the average maggot weight without an application of fly attractant.

From the starch materials under day 6 without fly attractant; a minimum recorded weight value of $32 \mathrm{~g} / \mathrm{kg}$ was recorded with $43 \mathrm{~g} / \mathrm{kg}$ being the maximum recorded weight value. While $37.75 \mathrm{~g} / \mathrm{kg}$ was the average weight.

From Figure 3, it can be observed that the starch and banana boxplots have the median lines to the middle, indicating that the data distribution is symmetric or normal. However, the median line is observed to be closer to the lower quartile meaning that the data constitute a higher frequency of high concentration values than the low concentration values ("positively skewed").

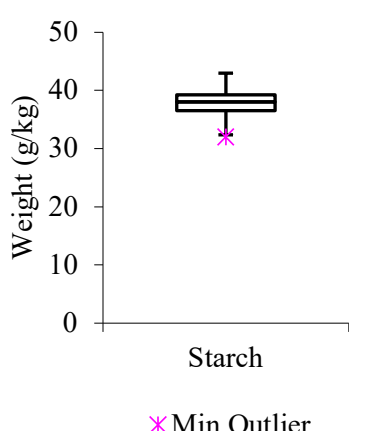

* Min Outlier

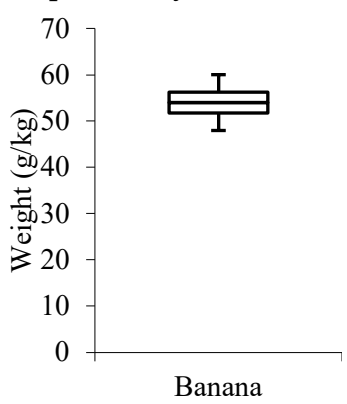

(b)

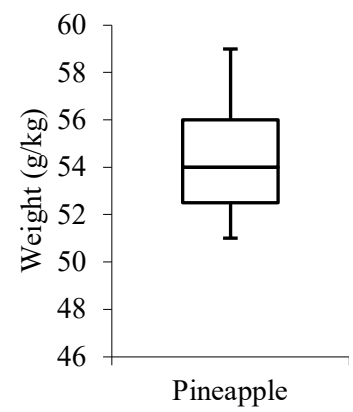

(c)

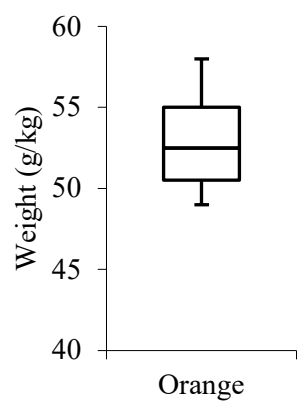

(d) 
(a)

Figure 3. Day 6 harvesting with the substrate without fly attractant from different waste materials (a) starch (b) bananas (c) pineapples (d) oranges

From banana (day 7), $55 \mathrm{~g} / \mathrm{kg}$ was recorded as the minimum maggot weight, with 70 $\mathrm{g} / \mathrm{kg}$ being the maximum recorded weight. While $62.25 \mathrm{~g} / \mathrm{kg}$ was the average weight from the banana materials and day 7 when the substrates were cultured without an application of fly attractant. From orange materials (day 7) without application of fly attractant; a minimum value of $52 \mathrm{~g} / \mathrm{kg}$ maggot weight was recorded; a maximum value of $68 \mathrm{~g} / \mathrm{kg}$ was recorded and an average weight of $60 \mathrm{~g} / \mathrm{kg}$ was recorded from the list of datasets.

From the pineapple materials (day 7); $56 \mathrm{~g} / \mathrm{kg}$ was recorded as the minimum weight value and $68 \mathrm{~g} / \mathrm{kg}$ was recorded as the maximum weight value, while $61.5 \mathrm{~g} / \mathrm{kg}$ was the average maggot weight without an application of fly attractant.

Moreover, from the starch materials without fly attractant; a minimum recorded wight value of $32 \mathrm{~g} / \mathrm{kg}$ was recorded with $42 \mathrm{~g} / \mathrm{kg}$ being the maximum recorded weight value. While $38 \mathrm{~g} / \mathrm{kg}$ was the average weight.

From banana (day 8), $58 \mathrm{~g} / \mathrm{kg}$ was recorded as the minimum maggot weight, with

$69 \mathrm{~g} / \mathrm{kg}$ being the maximum recorded weight. While $63.5 \mathrm{~g} / \mathrm{kg}$ was the average weight from the banana materials and day 8 when the substrates were cultured without an application of fly attractant. From orange materials (day 8 ) without application of fly attractant; a minimum value of $55 \mathrm{~g} / \mathrm{kg}$ maggot weight was recorded; a maximum value of $68 \mathrm{~g} / \mathrm{kg}$ was recorded and an average weight of $61.25 \mathrm{~g} / \mathrm{kg}$ was recorded from the list of datasets.

From the pineapple materials (day 8 ); $59 \mathrm{~g} / \mathrm{kg}$ was recorded as the minimum weight value and $68 \mathrm{~g} / \mathrm{kg}$ was recorded as the maximum weight value, while $62.5 \mathrm{~g} / \mathrm{kg}$ was the average maggot weight without an application of fly attractant.

Moreover, from the starch materials without fly attractant; a minimum recorded wight value of $35 \mathrm{~g} / \mathrm{kg}$ was recorded with $42 \mathrm{~g} / \mathrm{kg}$ being the maximum recorded weight value. While $39.25 \mathrm{~g} / \mathrm{kg}$ was the average weight.

From Figure 4 we can understand the median lines for almost all the boxplots are located somewhere closer to the middle of the plots. This means, there were no significant deviations among the experiments conducted for each material when the substrates were cultured without the application of fly attractant.
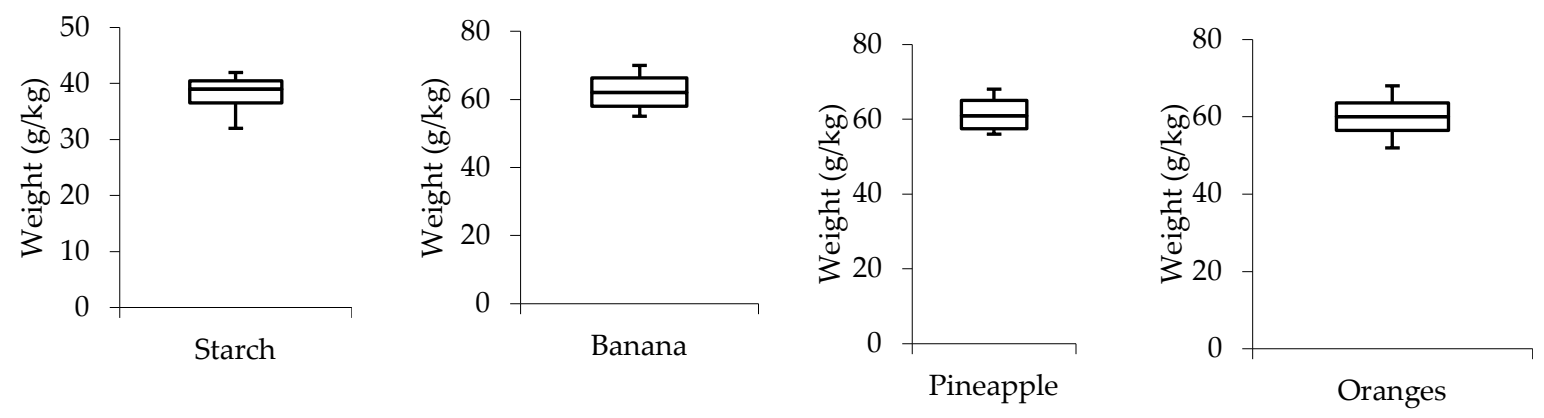

(a) 

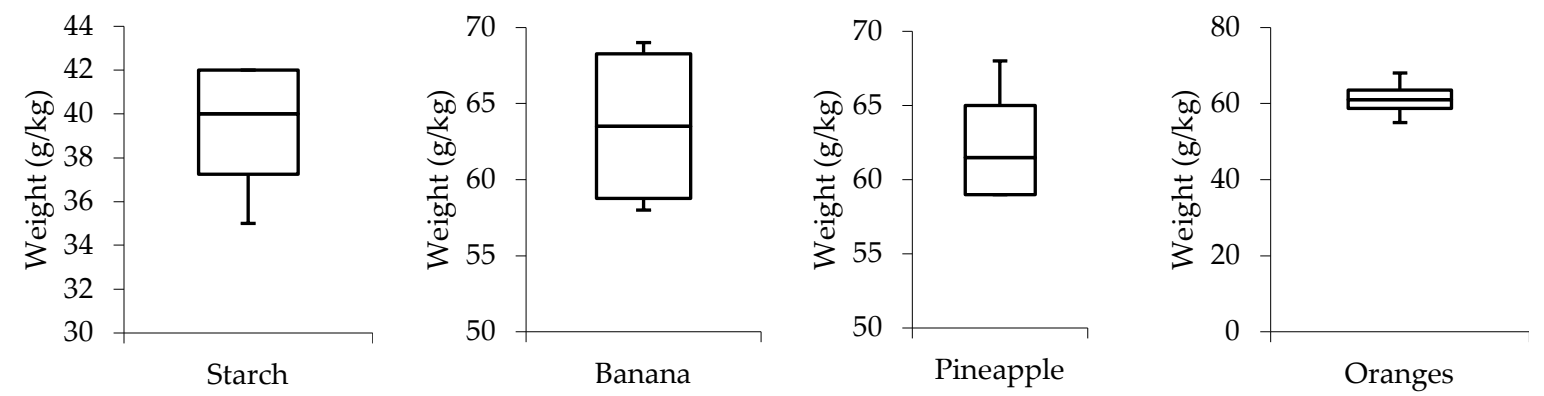

(b)

Figure 4 . The substrate without fly attractant from different waste materials (a) day 7 (b) day 8

The relationship among the key factors investigated in this study was also checked using correlation matrices. From Table 2 it can be observed that, when the substrates were cultured without an application of fly attractant, there was a very high (positive) correlation between the number of days to harvesting and the average maggot weight with a correlation index of 0.96 . However, the correlation between $\mathrm{pH}$ and weight of the maggots and the number of days is a bit less, and this is probably due to the fact that $\mathrm{pH}$ did not change for some of the days especially during the last days whereby $\mathrm{pH}$ remained almost constant while the weight of the maggots was changing. The observation from this study is similar to the study that investigated the impact of $\mathrm{pH}$ and feeding system specifically on black soldier fly (Hermetia illucens, L; Diptera: Stratiomyidae) larval development conducted by Marco Meneguz, Laura Gasco, and Jeffery K. Tomberlin [35]. In the study, it was observed that $\mathrm{pH}$ treatments impacted larval weight on some of the days, but not at the end of the trial.

Table 2. Relationship among maggot weight, number of days to harvesting, and $\mathrm{pH}$ from substrates without fly attractants

\begin{tabular}{cccc}
\hline & Number of days & $\begin{array}{c}\text { Average maggot } \\
\text { weight }\end{array}$ & $\mathrm{pH}$ \\
\hline $\begin{array}{c}\text { Number of days } \\
\text { Average maggot } \\
\text { weight }\end{array}$ & 1 & 1 & \\
$\mathrm{pH}$ & 0.96 & 0.66 & 1 \\
\hline
\end{tabular}

From Figure 4 it can be observed that the number of days had a significant effect on the average weights of the maggots. However, the extent to which the number of days affected the maggot weight differed depending on the type of substrate materials used. In this study, a gradual effect was observed from starch materials, with a more significant effect observed from banana and pineapple materials especially during the $7^{\text {th }}$ and $8^{\text {th }}$ day of the trial. On average, the highest average weight of $63.5 \mathrm{~g} / \mathrm{kg}$ was achieved from the banana materials followed by $62.5 \mathrm{~g} / \mathrm{kg}$ from pineapple materials during the $8^{\text {th }}$ day of the trial. However, the lowest maggot weight of $36 \mathrm{~g} / \mathrm{kg}$ can be observed from the $5^{\text {th }}$ day of the trial under starch materials without fly attractant. In the literature, general feeding conditions including type of substrate material have also been observed to be among the crucial decisive factors for maggot production as it affects nutrition during the larvae period [36]. 


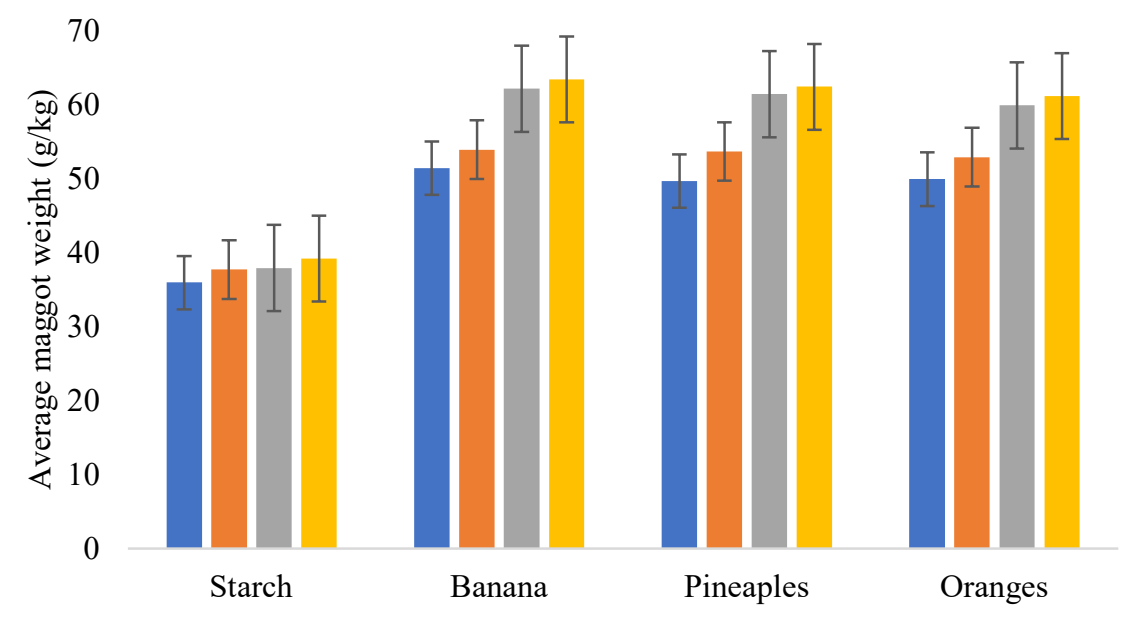

- Day 5 Day $6 \quad$ Day $7 \quad$ Day 8

Figure 5. Average maggot weight from the substrates without fly attractant

Similarly, as observed to the substrates with fly attractant, a strong relationship (positive correlation) between the number of days to harvesting and the average maggot weight can be observed with a correlation index of 0.87 (Table 3). However, as previously mentioned, the unpredictable changes in $\mathrm{pH}$ led to a moderate correlation between the $\mathrm{pH}$ and average maggot weight with a correlation index of 0.48 .

Table 3. Relationship among maggot weight, number of days to harvesting, and $\mathrm{pH}$ from substrates mixed with a fly attractant

\begin{tabular}{cccc}
\hline & Number of days & $\begin{array}{c}\text { Average maggot } \\
\text { weight }\end{array}$ & $\mathrm{pH}$ \\
\hline $\begin{array}{c}\text { Number of days } \\
\text { Average maggot } \\
\text { weight } \\
\mathrm{pH}\end{array}$ & 1 & 1 & \\
\hline
\end{tabular}

From banana (day 5), $81 \mathrm{~g} / \mathrm{kg}$ was recorded as the minimum maggot weight, with

$92 \mathrm{~g} / \mathrm{kg}$ being the maximum recorded weight. While $\quad 86.25 \mathrm{~g} / \mathrm{kg}$ was the average weight from the banana materials and day 5 when the substrates were cultured with an application of fly attractant. From orange materials (day 5) with an application of fly attractant; a minimum value of $80 \mathrm{~g} / \mathrm{kg}$ maggot weight was recorded; a maximum value of $90 \mathrm{~g} / \mathrm{kg}$ was recorded and an average weight of $83.25 \mathrm{~g} / \mathrm{kg}$ was recorded from the list of datasets.

From the pineapple materials (day 5 ); $78 \mathrm{~g} / \mathrm{kg}$ was recorded as the minimum weight value and $86 \mathrm{~g} / \mathrm{kg}$ was recorded as the maximum weight value, while $81.5 \mathrm{~g} / \mathrm{kg}$ was the average maggot weight with an application of fly attractant.

Moreover, from the starch materials with fly attractant; a minimum recorded wight value of $69 \mathrm{~g} / \mathrm{kg}$ was recorded with $86 \mathrm{~g} / \mathrm{kg}$ being the maximum recorded weight value. While $78.25 \mathrm{~g} / \mathrm{kg}$ was the average weight.

From banana (day 6), $88 \mathrm{~g} / \mathrm{kg}$ was recorded as the minimum maggot weight, with $102 \mathrm{~g} / \mathrm{kg}$ being the maximum recorded weight. While $92.5 \mathrm{~g} / \mathrm{kg}$ was the average weight from the banana materials and day 6 when the substrates were cultured with an 

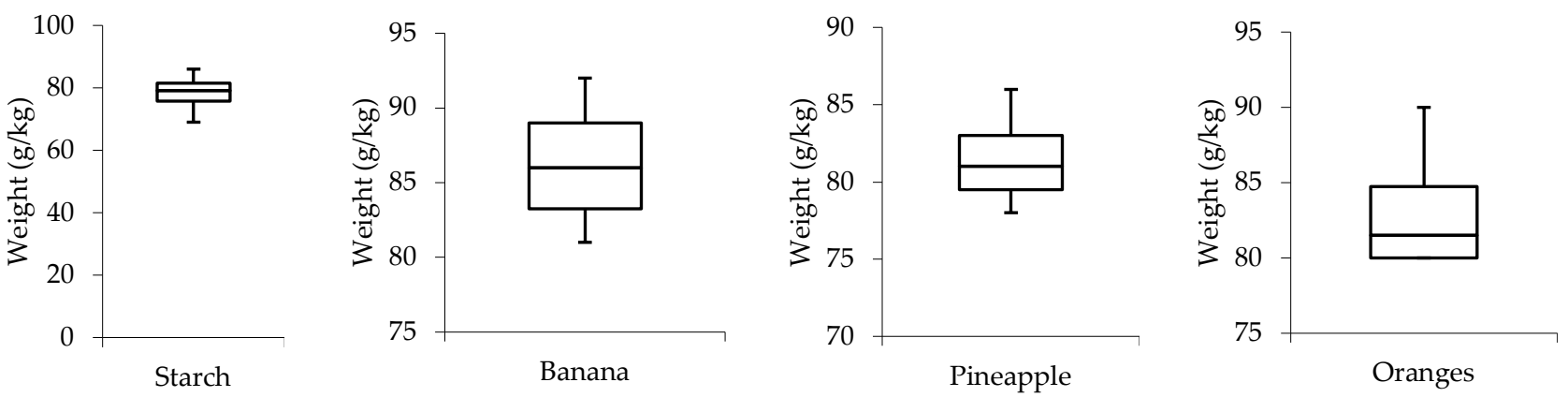

(a)
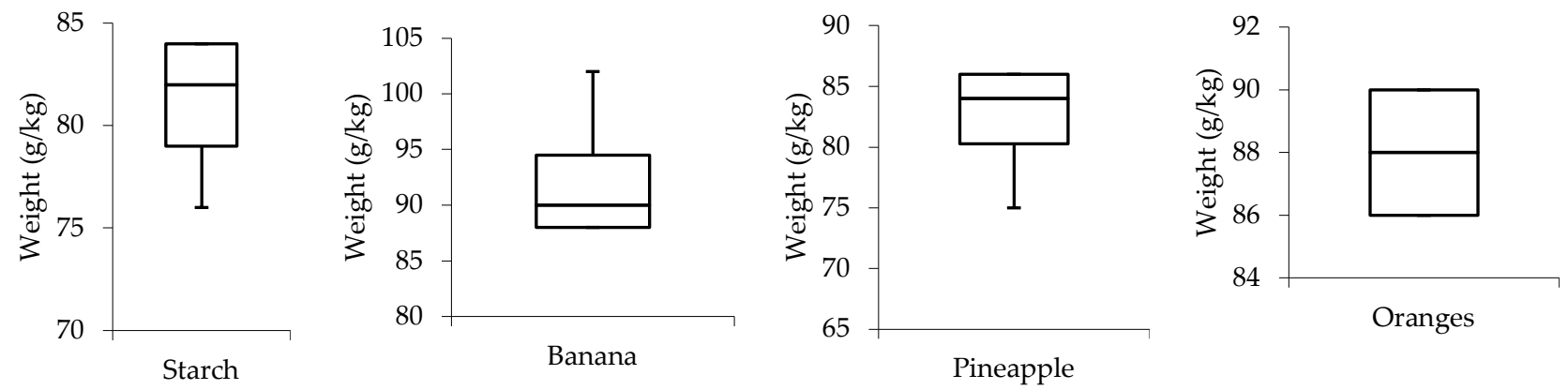

(b)

Figure 6. The substrate with fly attractant from different waste materials (a) day 5 (b) day 6

The combination of day 7 and banana materials accompanied by the application of fly attractant produced $88 \mathrm{~g} / \mathrm{kg}$ as the minimum recorded maggot weight, with $104 \mathrm{~g} / \mathrm{kg}$ being the maximum recorded weight. While $93.25 \mathrm{~g} / \mathrm{kg}$ was the average weight from the banana materials and day 7 when the substrates were cultured with an application of fly attractant. From orange materials (day 7) with an application of fly attractant; a minimum 


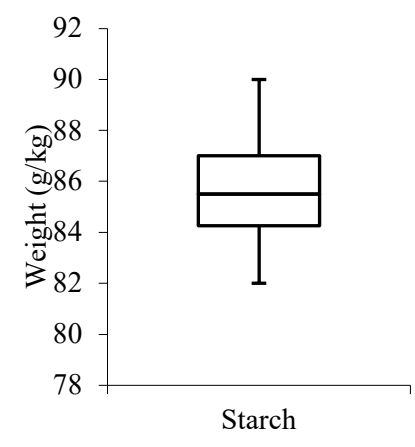

(a) value of $83 \mathrm{~g} / \mathrm{kg}$ maggot weight was recorded; a maximum value of $95 \mathrm{~g} / \mathrm{kg}$ was recorded and an average weight of $88.5 \mathrm{~g} / \mathrm{kg}$ was recorded from the list of datasets.

From the pineapple materials (day 7); $83 \mathrm{~g} / \mathrm{kg}$ was recorded as the minimum weight value and $96 \mathrm{~g} / \mathrm{kg}$ was recorded as the maximum weight value, while $88.25 \mathrm{~g} / \mathrm{kg}$ was the average maggot weight without an application of fly attractant.

The starch materials with fly attractant during day 8 of culturing produced a minimum recorded weight value of $82 \mathrm{~g} / \mathrm{kg}$ was recorded with $90 \mathrm{~g} / \mathrm{kg}$ being the maximum recorded weight value. While $85.75 \mathrm{~g} / \mathrm{kg}$ was the average weight.

From Figure 5, it can be observed that from the starch and oranges substrate material boxplots have the median line closer to the middle, indicating that the data distribution is symmetric or normal. From the banana and pineapple boxplots, the median line is observed to be closer to the lower quartile meaning that the data constitute a higher frequency of high concentration values than the low concentration values ("positively skewed").

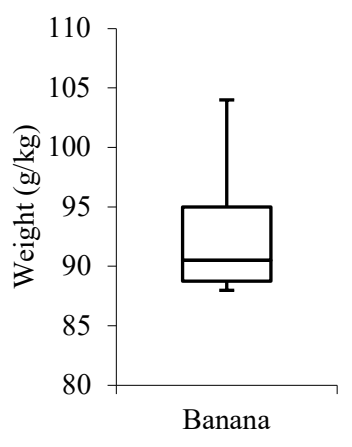

(b)

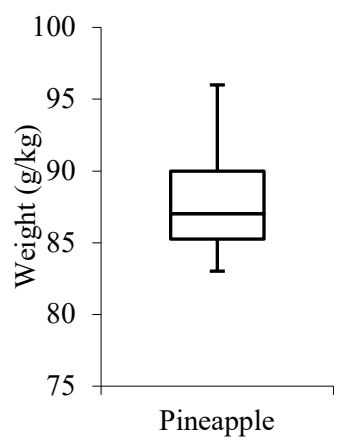

(c)

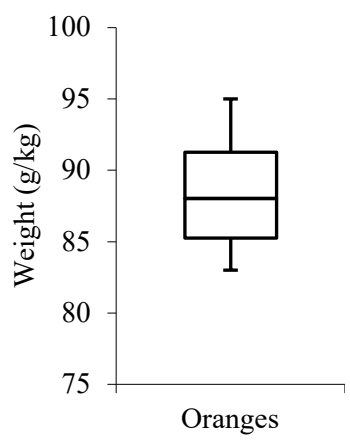

(d)
Figure 6. Day 7 harvesting from substrate mixed with fly attractant from different waste materials (a) starch (b) bananas (c) pineapples (d) oranges

From banana (day 8), $84 \mathrm{~g} / \mathrm{kg}$ was recorded as the minimum maggot weight, with $112 \mathrm{~g} / \mathrm{kg}$ being the maximum recorded weight. While $94 \mathrm{~g} / \mathrm{kg}$ was the average weight from the banana materials and day 6 when the substrates were cultured with an application of fly attractant. From orange materials (day 8) with an application of fly attractant; a minimum value of $86 \mathrm{~g} / \mathrm{kg}$ maggot weight was recorded; a maximum value of $108 \mathrm{~g} / \mathrm{kg}$ was recorded and an average weight of $93 \mathrm{~g} / \mathrm{kg}$ was recorded from the list of datasets.

The combination of pineapple materials, day 8 and with an application of fly attractant produced $78 \mathrm{~g} / \mathrm{kg}$ as the minimum recorded weight value and $96 \mathrm{~g} / \mathrm{kg}$ was recorded as the maximum weight value, while $85.5 \mathrm{~g} / \mathrm{kg}$ was the average maggot weight with an application of fly attractant.

While from the starch materials with fly attractant; a minimum recorded wight value of $79 \mathrm{~g} / \mathrm{kg}$ was recorded with $90 \mathrm{~g} / \mathrm{kg}$ being the maximum recorded weight value. While $86.5 \mathrm{~g} / \mathrm{kg}$ was the average weight.

From Figure 6, it can be observed that the starch boxplot has its median line closer to the upper quartile with an indication that the distribution is "negatively skewed". This means the data constituted a higher frequency of low concentration values than the high concentration values. From the banana, pineapple, and orange boxplots, the median line can be observed to be closer to the lower quartile meaning that the water quality data constitute a higher frequency of high concentration values than the low concentration values ("positively skewed"). 


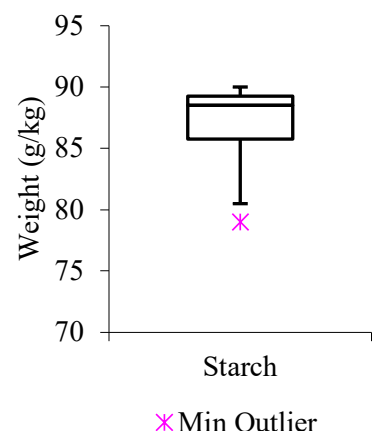

(a)

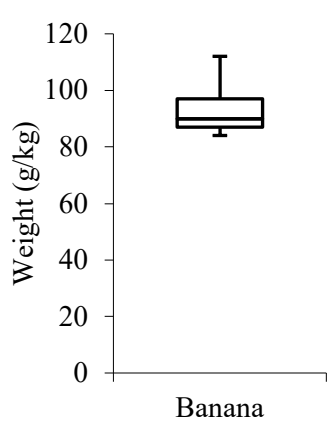

(b)

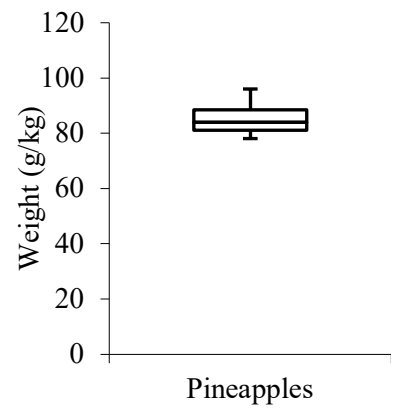

(c)

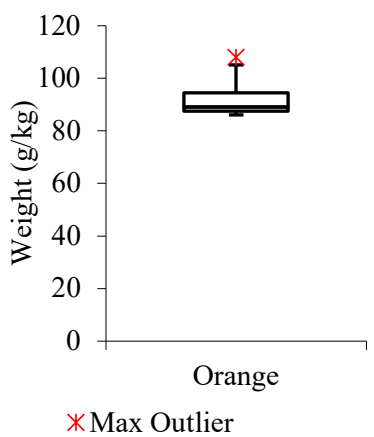

(d)

Figure 7. Day 8 harvesting from substrate mixed with fly attractant from different waste materials (a) starch (b) bananas (c) pineapples (d) oranges

The application of fly attractant was observed to improve the maggot yield significantly. From Figure 7 it can be observed that up to $94 \mathrm{~g} / \mathrm{kg}$ of maggot weight was achieved from banana materials from the $8^{\text {th }}$ day of the cultivation. Which is an increase of $32.4 \%$ from the same day, the same material with no application of fly attractant. Also, from the starch materials, about $77 \mathrm{~g} / \mathrm{kg}$ of maggot weight was achieved; which is an increase of $49 \%$ from the day and the same material when the substrate was cultured without application of fly attractant. However, despite the spontaneous increase in the average maggot weight when the fly attractant was applied to the substrates, the effect of the number of days to harvesting was minimum for some of the materials compared to when the fly attractant was not applied to the substrates. An interesting phenomenon can be observed from day 8 with pineapple materials, where the average maggot weight reduced by approximately $3 \%$. However, such a phenomenon can be linked to a number of factors, including predation, changes in environmental conditions as well as some unknown potential issues related to the substrate condition in the particular day.

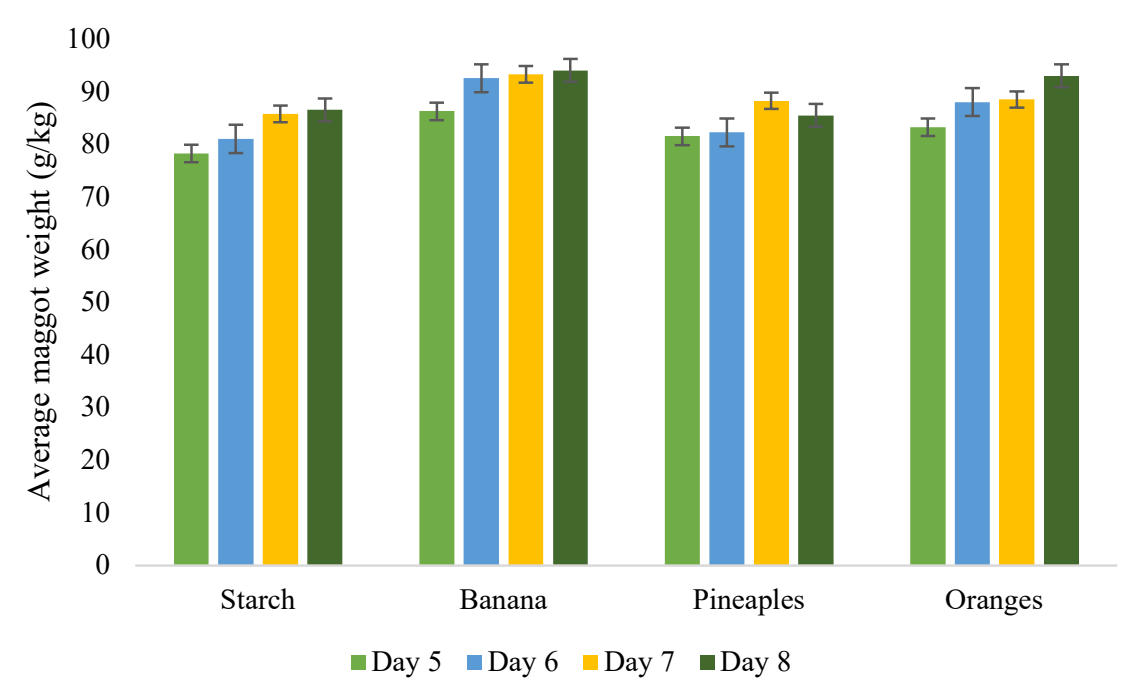

Figure 8. Average maggot weight from substrate mixed with a fly attractant

In general, the relative dry weight reduction in the trials varied from $52.5 \%$ to $82.4 \%$ (Figure 8). As previously observed that, the application fly attractant increased the number of maggots that affected the weight after harvesting; the amount of the remaining 
waste after harvesting was also observed to be corresponding to the number of maggots in a breeding vat. Whereby, breeding vats with more maggots ended up with a little amount of waste remaining. In this study, the highest waste reduction was achieved from the combination of 8 days and banana waste materials with a waste reduction efficiency of $82.4 \%$. In the literature, maggots have also been observed to be highly efficient in organic waste reduction [37].

Moreover, during the experiments, it was observed after some time the cultivation vats were generating a considerable amount of liquid that in turn created anaerobic and foul-smelling conditions. Those places with accumulated liquid were observed to be not conducive for maggots as none of the maggots was observed in those places. In that matter, it is always important to design cultivation vats with some drainage provision to avoid an accumulation of liquid that would affect the productivity of the system

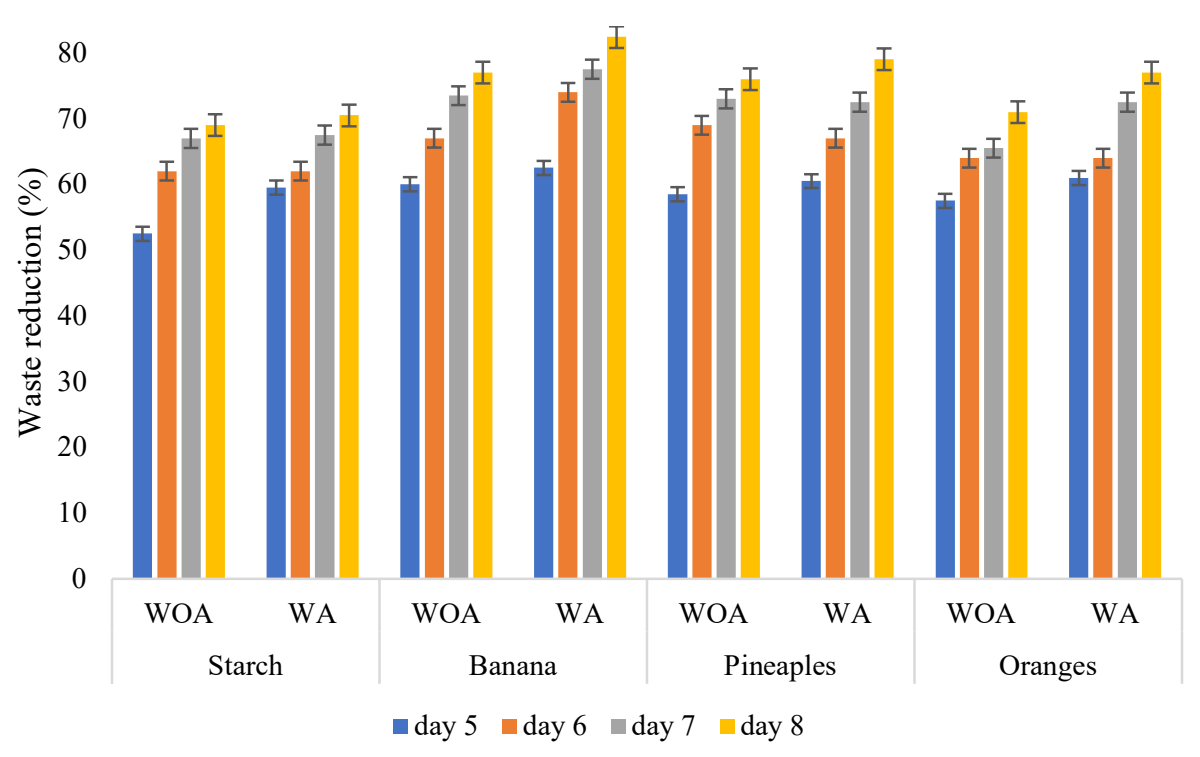

Figure 9. Relative dry weight waste reduction; $\mathrm{WOA}=$ without attractant, $\mathrm{WA}=$ with attractant

\section{Conclusions}

The potential of recovering food waste through maggots' production as animal feed has been investigated. The influence of the time and fly attractant application on maggot production has also been investigated. From the results, it was observed that the application of fly attractant improved the maggot yield significantly. Up to $94 \mathrm{~g} / \mathrm{kg}$ of maggot weight was achieved from banana materials during the 8th day of the cultivation. Which is an increase of $32.4 \%$ from the same day, the same material with no application of fly attractant. Also, from the starch materials, about $77 \mathrm{~g} / \mathrm{kg}$ of maggot weight was achieved; which is an increase of $49 \%$ from the day and the same material when the substrate was cultured without application of fly attractant. However, despite the spontaneous increase in the average maggot weight when the fly attractant was applied to the substrates, the effect of the number of days to harvesting was minimum for some of the materials compared to when the fly attractant was not applied to the substrates. Moreover, the relative dry weight reduction in the trials varied from $52.5 \%$ to $82.4 \%$. In general, the maggots showed remarkable ability to transform the organic waste (starch, banana, pineapple, and oranges) into high-quality protein, all while leaving a smaller carbon footprint than it found. 


\begin{abstract}
Author Contributions: Conceptualization, T.M. and K.M.; methodology, T.M..; software, G.B., A.K., T.M., and A.Ka.; validation, A.T., G.B., A.K., and A.Ka.; formal analysis, T.M.; investigation, resources, and data curation, K.M, G.B.., A.K., and T.M.; writing-original draft preparation, T.M.; writing-review and editing, K.M., A.K., and T.M.; visualization, T.M.; supervision, project administration, and funding acquisition, K.M.; All authors have read and agreed to the published version of the manuscript.
\end{abstract}

Funding: This research was funded by the Ministry of Education and Science, the Republic of Kazakhstan to support "Reducing the technogenic impact on water resources with using water recycling technology", № BR05236844 /215 for 2018- 2020 years.

Conflicts of Interest: The authors declare no conflict of interest. The funders had no role in the design of the study; in the collection, analyses, or interpretation of data; in the writing of the manuscript, or in the decision to publish the results.

Institutional Review Board Statement: Not applicable

Informed Consent Statement: Not applicable

Data Availability Statement: Not applicable

\title{
References
}

1. Hartikainen, H.; Mogensen, L.; Svanes, E.; Franke, U. Food waste quantification in primary production - The Nordic countries as a case study. Waste Manag. 2018, 71, 502-511, doi:10.1016/j.wasman.2017.10.026.

2. Yu, Y.; Jaenicke, E.C. Estimating Food Waste as Household Production Inefficiency. Am. J. Agric. Econ. 2020, 102, 525-547, doi:10.1002/ajae.12036.

3. Parizeau, K.; von Massow, M.; Martin, R. Household-level dynamics of food waste production and related beliefs, attitudes, and behaviours in Guelph, Ontario. Waste Manag. 2015, 35, 207-217, doi:10.1016/j.wasman.2014.09.019.

4. Skoet, J.; Fabi, C.; Cattaneo, A. Measuring Food Loss and Waste: An <scp $>$ FAO</scp $>$ Perspective. EuroChoices 2020, 19, 2223, doi:10.1111/1746-692X.12251.

5. David, V.E.; John, Y.; Hussain, S. Rethinking sustainability: a review of Liberia's municipal solid waste management systems, status, and challenges. J. Mater. Cycles Waste Manag. 2020, 22, 1299-1317, doi:10.1007/s10163-020-01046-x.

6. Spoann, V.; Fujiwara, T.; Seng, B.; Lay, C.; Yim, M. Assessment of Public-Private Partnership in Municipal Solid Waste Management in Phnom Penh, Cambodia. Sustainability 2019, 11, 1228, doi:10.3390/su11051228.

7. Lee, U.; Han, J.; Wang, M. Evaluation of landfill gas emissions from municipal solid waste landfills for the life-cycle analysis of waste-to-energy pathways. J. Clean. Prod. 2017, 166, 335-342, doi:10.1016/j.jclepro.2017.08.016.

8. Al-Rumaihi, A.; McKay, G.; Mackey, H.R.; Al-Ansari, T. Environmental impact assessment of food waste management using two composting techniques. Sustain. 2020, doi:10.3390/su12041595.

9. Marashlian, N.; El-Fadel, M. The effect of food waste disposers on municipal waste and wastewater management. Waste Manag. Res. J. a Sustain. Circ. Econ. 2005, 23, 20-31, doi:10.1177/0734242X05050078.

10. Maalouf, A.; El-Fadel, M. Effect of a food waste disposer policy on solid waste and wastewater management with economic implications of environmental externalities. Waste Manag. 2017, 69, 455-462, doi:10.1016/j.wasman.2017.08.008.

11. Akturk, A.S.; Demirer, G.N. Improved Food Waste Stabilization and Valorization by Anaerobic Digestion Through Supplementation of Conductive Materials and Trace Elements. Sustainability 2020, 12, 5222, doi:10.3390/su12125222.

12. Cyril, K.M.; Rodrigue, K.A.; Essi, K.; Albert, T.; Agboue, A. Biochemical Methane Potential of Food Wastes from Akouedo Landfill, C\&amp;\#244;te d'Ivoire. Green Sustain. Chem. 2018, 08, 288-293, doi:10.4236/gsc.2018.83019.

13. Shehzad, A.; Bashir, M.J.K.; Sethupathi, S.; Lim, J.-W. An overview of heavily polluted landfill leachate treatment using food waste as an alternative and renewable source of activated carbon. Process Saf. Environ. Prot. 2015, 98, 309-318, doi:10.1016/j.psep.2015.09.005.

14. Pahla, G.; Ntuli, F.; Muzenda, E. Torrefaction of landfill food waste for possible application in biomass co-firing. Waste Manag. 2018, 71, 512-520, doi:10.1016/j.wasman.2017.10.035. 
15. He, H.; Gao, S.; Hu, J.; Zhang, T.; Wu, T.; Qiu, Z.; Zhang, C.; Sun, Y.; He, S. In-Situ Testing of Methane Emissions from Landfills Using Laser Absorption Spectroscopy. Appl. Sci. 2021, 11, 2117, doi:10.3390/app11052117.

16. Kweku, D.; Bismark, O.; Maxwell, A.; Desmond, K.; Danso, K.; Oti-Mensah, E.; Quachie, A.; Adormaa, B. Greenhouse Effect: Greenhouse Gases and Their Impact on Global Warming. J. Sci. Res. Reports 2018, doi:10.9734/jsrr/2017/39630.

17. Smith, P.; Martino, D.; Cai, Z.; Gwary, D.; Janzen, H.; Kumar, P.; McCarl, B.; Ogle, S.; O’Mara, F.; Rice, C.; et al. Greenhouse gas mitigation in agriculture. Philos. Trans. R. Soc. B Biol. Sci. 2008, 363, 789-813, doi:10.1098/rstb.2007.2184.

18. Tuckett, R. Greenhouse Gases. In Reference Module in Chemistry, Molecular Sciences and Chemical Engineering; Elsevier, 2018 ISBN 9780081019832.

19. Makkar, H.P.S.; Tran, G.; Heuzé, V.; Ankers, P. State-of-the-art on use of insects as animal feed. Anim. Feed Sci. Technol. 2014, 197, 1-33, doi:10.1016/j.anifeedsci.2014.07.008.

20. Fauzi, R.U.A.; Sari, E.R.N. Business Analysis of Maggot Cultivation as a Catfish Feed Alternative. Ind. J. Teknol. dan Manaj. Agroindustri 2018, 7, 39-46, doi:10.21776/ub.industria.2018.007.01.5.

21. Zhu, F.-X.; Wang, W.-P.; Hong, C.-L.; Feng, M.-G.; Xue, Z.-Y.; Chen, X.-Y.; Yao, Y.-L.; Yu, M. Rapid production of maggots as feed supplement and organic fertilizer by the two-stage composting of pig manure. Bioresour. Technol. 2012, 116, 485-491, doi:10.1016/j.biortech.2012.04.008.

22. Gilbert, C.Z.T.; Abdourhamane, I.T.; Cédric, S.O.; Arsène, V.M.; Férence, N.M.; Taffarel, J.M.N.; Kady, D.M.G.; Frédéric, C.N.N.; Joseph-Privat, O.; Louis, C.O.E.; et al. Comparative study of maggots production in brewery wet grains, dung and rumen content of cattle with or without addition of attractant. African J. Biotechnol. 2020, 19, 773-780, doi:10.5897/AJB2020.17204.

23. Coulibaly, K.; Sankara, F.; Pousga, S.; Nacoulma, P.J.; Somé, M.B.; Nacro, H.B. On station maggot production using poultry litter as substrate: assessment on the quantity and the chemical quality of the litter before and after maggot production in Burkina Faso. Int. J. Biol. Chem. Sci. 2020, 14, 1689-1697, doi:10.4314/ijbcs.v14i5.16.

24. Føre, M.; Frank, K.; Norton, T.; Svendsen, E.; Alfredsen, J.A.; Dempster, T.; Eguiraun, H.; Watson, W.; Stahl, A.; Sunde, L.M.; et al. Precision fish farming: A new framework to improve production in aquaculture. Biosyst. Eng. 2018, 173, 176-193, doi:10.1016/j.biosystemseng.2017.10.014.

25. Rumpold, B.A.; Speckmann, H.; Schlüter, O.; Kloas, W.; Prochnow, A. Potentials of a biogenic residue-based production of Hermetia illucens as fish meal replacement in aquafeed for Oncorhynchus mykiss in Germany. J. Insects as Food Feed 2018, 4, 5-18, doi:10.3920/JIFF2016.0060.

26. Hossain, M.M.; Chakraborty, S.C. Growth and economic analysis of freshwater prawn, Macrobrachium rosenbergii (de Man), produced with feeds substituting sunflower cake for fish meal, soya bean meal and mustard oil cake. Aquac. Res. 2017, 48, 5418-5429, doi:10.1111/are.13357.

27. Liang, Y.; Cheung, R.Y..; Everitt, S.; Wong, M.. Reclamation of wastewater for polyculture of freshwater fish: fish culture in ponds. Water Res. 1999, 33, 2099-2109, doi:10.1016/S0043-1354(98)00420-5.

28. Reddy, D.V. The effect of supplementation of legume straws on utilisation of rice straw-poultry droppings-rice bran-fish meal based diet in buffaloes. Anim. Feed Sci. Technol. 1997, 69, 305-314, doi:10.1016/S0377-8401(97)00062-X.

29. Al-Abri, A.S.; Mahgoub, O.; Kadim, I.T.; Al-Marzooqi, W.; Goddard, S.R. Effects of feeding fish-wheat bran meal on performance and meat quality of Omani sheep. J. Appl. Anim. Res. 2017, 45, 234-238, doi:10.1080/09712119.2016.1150843.

30. Mengesha, M. The issue of feed-food competition and chicken production for the demands of foods of animal origin. Asian J. Poult. Sci. 2012, doi:10.3923/ajpsaj.2012.31.43.

31. Skunca, D.; Tomasevic, I.; Nastasijevic, I.; Tomovic, V.; Djekic, I. Life cycle assessment of the chicken meat chain. J. Clean. Prod. 2018, 184, 440-450, doi:10.1016/j.jclepro.2018.02.274.

32. Linhares, J.E.; Pessa, S.L.R.; Oliveira, G.A.; Trentin, M.G. Ergonomic analysis in an animal feed company: demands and work 
environment. Rev. Gestão Ind. 2018, 14, doi:10.3895/gi.v14n2.6966.

33. Moretti, E.; Wickings, K.; Nault, B. Environmental factors and crop management that affect Delia antiqua damage in onion fields. Agric. Ecosyst. Environ. 2021, 314, 107420, doi:10.1016/j.agee.2021.107420.

34. Geddes, P.S.; LeBlanc, J.-P.R.; Yule, W.N. Abiotic and biotic factors affecting Rhagoletis mendax [Diptera :Tephritidae] populations in eastern Canadian lowbush blueberry fields. Phytoprotection 2005, 73, 73-78, doi:10.7202/706022ar.

35. Meneguz, M.; Gasco, L.; Tomberlin, J.K. Impact of pH and feeding system on black soldier fly (Hermetia illucens, L; Diptera: Stratiomyidae) larval development. PLoS One 2018, doi:10.1371/journal.pone.0202591.

36. Kim, C.-H.; Ryu, J.; Lee, J.; Ko, K.; Lee, J.; Park, K.Y.; Chung, H. Use of Black Soldier Fly Larvae for Food Waste Treatment and Energy Production in Asian Countries: A Review. Processes 2021, 9, 161, doi:10.3390/pr9010161.

37. Negi, S.; Mandpe, A.; Hussain, A.; Kumar, S. Collegial effect of maggots larvae and garbage enzyme in rapid composting of food waste with wheat straw or biomass waste. J. Clean. Prod. 2020, 258, 120854, doi:10.1016/j.jclepro.2020.120854. 